\title{
Application of the Multivariate Statistical Analysis for Hydrogeochemical Assessment of Groundwater of Coastal Aquifer AQ1 of Pointe-Noire, Congo
}

\author{
D. NKOUNKOU TOMODIATOUNGA ${ }^{1}$, L. MATINI $^{2}$, L. OKOTAKA EBALÉ ${ }^{1}$, \\ G. MOUKANDI N'KAYA ${ }^{1}$ and B. MABIALA ${ }^{1}$
}

${ }^{1}$ Laboratoire Mécanique, Energétique et Ingénierie, Ecole Nationale Supérieure Polytechnique, Université Marien Ngouabi, B.P. 69 Brazzaville, Rép. Du Congo

${ }^{2}$ Laboratoire de chimie minérale et appliquée, Faculté des Sciences Université Marien Ngouabi, B.P. 69 Brazzaville, Rép. Du Congo

dnkounkou@yahoo.fr

Received 19 October 2017 / Accepted 16 November 2017

\begin{abstract}
The physicochemical quality of groundwater of one of the five aquifers of the coastal region of Pointe-Noire, aquifer AQ1 is the subject of this study. Water of 18 wells was taken during the year 2014. 13 variables were given in the water samples: pH, C.E, T, $\mathrm{Ca}^{2+}, \mathrm{Mg}^{2+}, \mathrm{Na}^{+}, \mathrm{K}^{+}$, $\mathrm{HCO}_{3}{ }^{-}, \mathrm{Cl}^{-}, \mathrm{SO}_{4}{ }^{2-}, \mathrm{NO}_{3}{ }^{-}$, TDS and TH. The $\mathrm{pH}$ lies between 4.26 and $7.10 .88 .88 \%$ of the wells have $\mathrm{pH}$ lower to 6.5 , which show the acid character. $83.33 \%$ of analysed water are fairly mineral-bearing (C.E $<300 \mu \mathrm{S} \mathrm{cm}^{-1}$ ). On the other hand $16.67 \%$ of these water wells (PU1, PU4 and PU17) present an accentuated mineralization. The multivariate statistical methods have been used in this study. Ascending hierarchical classification gave two groups of water well. Except for the temperature and $\mathrm{pH}$, the other variables discriminate the two groups. The factorial analysis highlighted two factors which account for $80.61 \%$ of the total variance. The first factor $(62.87 \%)$ shows the mineralization and the hardness water. The second factor $(17.74 \%)$ highlights the dissolution of carbonated minerals of magnesium and the character slightly acid of water.
\end{abstract}

Keywords: Groundwater, Multivariate statistical analysis, Pointe-Noire Congo

\section{Introduction}

In the African countries, the access to the drinkable water resources is an economic problem and of major public health. Many areas of the continent exploit the underground sheets of water to satisfy the daily of the households, the industrial and agricultural needs.

In the particular case of Congo, the zone of the littoral of Pointe-Noire has two groundwater, one superficial and the other deep one confined. The problems arising from the exploitation of ancoastal aquifer are generally delicate for they associate the concept of quantity with that of quality. The intensive use of the natural resources and the increase in human activities generated serious problems on water quality groundwater ${ }^{1,2}$. 
However this quality can be faded when external substances come into contact with the aquifer. Such is the case of the even toxic undesirable substances which make subterranean water unsuitable for various uses in particular for the water use of drink.

The groundwater has physicochemical characteristics which are particular for it, such as the temperature, the color, the $\mathrm{pH}$, conductivity and the content of major elements. These characteristics resulting from the natural environment are very variable. They depend on the geological nature of the ground from where they come and also of the reactive substances which they could have met during the flow. Thus the quantitative and qualitative composition of subterranean water out of suspended matter and dissolved, of mineral or organic nature, determines its quality ${ }^{3}$.

\section{Experimental}

\section{Presentation of the zone of study}

The zone of study is the coastal sedimentary basin of Pointe-Noire, Congo located between the parallels $4^{\circ}$ and Southern $5^{\circ}$ and between the meridian lines $11^{\circ}$ and $12^{\circ}$ East, at the South-western end limited by the Atlantic Ocean (Figure 1). Its hydrogeology is structured in five aquifers ${ }^{4}$ (Figure 2):

- Aquifer not very deep AQ-1 (not confined), contains an unconfined water, corresponding to the medium saturated with the most permeable layers and more draining sands of surface.

- Aquifer deep AQ-2 (confined) contains an Artesian deep confined water in certain places, corresponding to the most permeable layers of the series of the circuses (quaternary). It consists of sometimes silteux heterogeneous sands alternating with the levels mudstones.

- Aquifer deep AQ-3 (confined), contains a confined water corresponding to the most permeable layers of ferruginous sands, consisted of sometimes conglomeratic heterogeneous sands alternating with ferruginous concretions.

- $\quad$ Aquifer deep AQ-4 (confined) contains also a confined water, resting on a substratum not very permeable and limited by a not very permeable superstratum also, corresponding to the least permeable layers of the greso-dolomitic series of the cretaceous (secondary), consists of clayey sands and dolomitic aggregates.

- The aquifer potential AQ-5, is a confined water known as potential corresponding to the unit of the dolomite and the calcite of the calcaro-dolomitic series in which losses of circulation were observed in certain mining structural test drillings.

The present study relates to aquifer AQ1.

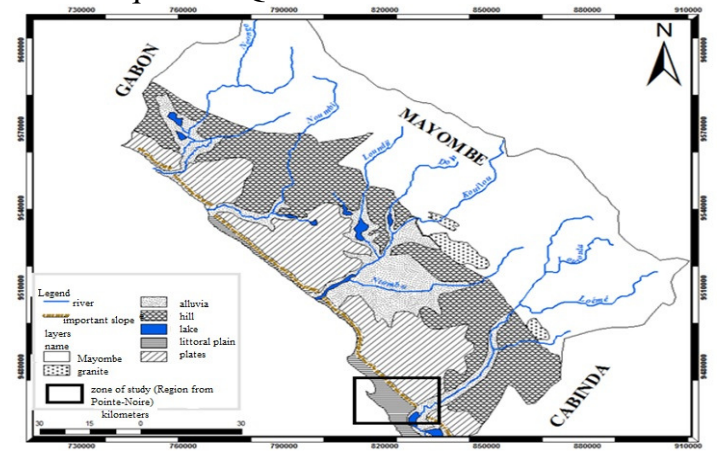

Figure 1. Geographical location of the coastal sedimentary basin ${ }^{5}$ 


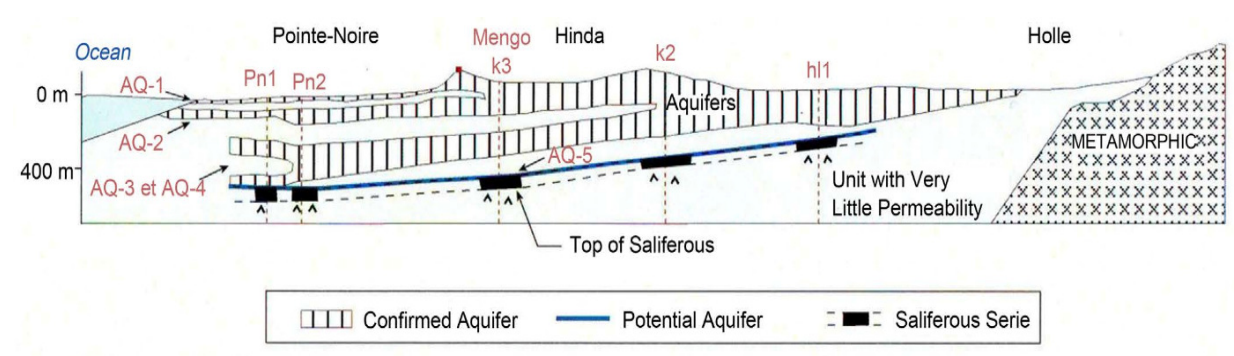

$0 \quad 2 \quad 4 \mathrm{~km}$

Figure 2. Coastal sedimentary aquiferous system ${ }^{6}$

The physicochemical analyses have been carried out on water of deprived wells of public use collecting the ground water of the complex hydrogeological of the area of Pointe-Noire, Congo. The taking away are carried out and conditioned in polyethylene bottles of $1 \mathrm{~L}$. These bottles were cleaned with the nitric acid then to rinse with distilled water several times. On the ground the bottles were also rinsed with water to take. These taking away are carried out using an especially designed sampler. The device of sampling is carefully washed with the water distilled before each taking away. The near total of the water points of the aquifers is intended for the drinking water supply. To be used, water must meet certain standards which vary according to the type of use. The water samples intended for the chemical analyses were taken in eighteen (18) wells of the urban area of Pointe-Noire (Figure 2). These samples were taken from January in December 2014. The samples of the rain season take into account the following months: November in April 2014. The month of May 2014 is regarded as a transition between the rain season and the dry season ${ }^{7}$.

The samples of the rainy season taken into account the following months: June in September 2014. For each analysis, physical parameters with knowing the $\mathrm{pH}$, the temperature and electric conductivity are measured in situ using a $\mathrm{pH}$-meter and of a conductometer of mark WTW 330. The water samples were immediately stored with $4{ }^{\circ} \mathrm{C}$ in a refrigerator containing of the ice, the analysis was carried out quickly with less of 24:00 after the taking away. The major elements calcium $\left(\mathrm{Ca}^{2+}\right)$, magnesium $\left(\mathrm{Mg}^{2+}\right)$, sodium $\left(\mathrm{Na}^{+}\right)$, potassium $\left(\mathrm{K}^{+}\right)$, chloride $\left(\mathrm{Cl}^{-}\right)$, bicarbonate $\left(\mathrm{HCO}_{3}{ }^{-}\right)$, sulphates $\left(\mathrm{SO}_{4}^{2-}\right)$ and total hardness were analysed in the laboratories of civil engineering of the Higher National Polytechnic School (ENSP), the Research institute in exact sciences and natural (IRSEN) and of the national company of water supply (SNDE). These analyses were carried out using a spectrophotometer by using the standardized traditional methods.

\section{Results and Discussion}

\section{Physicochemical analyses}

Tables 1 and 2 have the results of the physicochemical analysis of the samples in rainy season and dry season.

The temperature of water is an important climatic parameter which influences on many of other parameters. The temperature varies from $26.1{ }^{\circ} \mathrm{C}$ with $29.9{ }^{\circ} \mathrm{C}$ in rainy season with an average of $28.03{ }^{\circ} \mathrm{C} \pm 0.94{ }^{\circ} \mathrm{C}$ and $26.12{ }^{\circ} \mathrm{C}$ with $28.63{ }^{\circ} \mathrm{C}$ in dry season with an average of $27.57{ }^{\circ} \mathrm{C}$. The $\mathrm{pH}$ characterizes the concentration of a water or an aqueous solution in ions hydronium $\left(\mathrm{H}^{+}\right)$. The values of the $\mathrm{pH}$ of subterranean water vary from 4.10 and $7.10 \mathrm{in}$ 
rainy season with an average of 5.92 \pm 0.58 and 5.06 to 7.00 in dry season with an average of 6.13 , electric conductivity is the physical parameter which characterizes the conduction of the electric current by water. It varies in the sector between $20.5 \mu \mathrm{S} \mathrm{cm}^{-1}$ and $936.4 \mu \mathrm{S} \mathrm{cm}^{-1}$ in rain season des with an average $267.28 \pm 248.26 \mu \mathrm{S} \mathrm{cm}^{-1}$ and of $17.00 \mu \mathrm{S} \mathrm{cm}^{-1}$ to $697.00 \mu \mathrm{S} \mathrm{cm}^{-1}$ in dry season with an average of $176.94 \mu \mathrm{S} \mathrm{cm}^{-1}$.

Table 1. Physicochemical composition of the water samples of well in rain season

\begin{tabular}{|c|c|c|c|c|c|c|c|c|c|c|c|c|c|}
\hline Wells & $\mathrm{T}$ & $\mathrm{pH}$ & C.E & TDS & $\mathrm{Ca}^{2+}$ & $\mathrm{Mg}^{2+}$ & $\mathrm{Na}^{+}$ & $\mathrm{K}^{+}$ & $\mathrm{HCO}_{3}^{-}$ & $\mathrm{Cl}^{-}$ & $\mathrm{SO}_{4}{ }^{2-}$ & $\mathrm{NO}_{3}{ }^{-}$ & TH \\
\hline PU1 & 28.1 & 6.3 & 936.4 & 697.2 & 28.4 & 7.6 & 161.5 & 7.8 & 18.8 & 90.2 & 80.4 & 302.4 & 10.3 \\
\hline PU2 & 28.6 & 5.3 & 363.3 & 111.2 & 4.7 & 2.9 & 20.6 & 2.2 & 43.9 & 12.4 & 0.3 & 23.9 & 2.7 \\
\hline PU3 & 27.7 & 4.9 & 550.8 & 268.7 & 10.9 & 4.3 & 54.6 & 14.3 & 12.2 & 46.7 & 36 & 88.9 & 4.7 \\
\hline PU4 & 28.1 & 6.1 & 542 & 396.8 & 16.6 & 2.5 & 99.7 & 7.6 & 14.5 & 77.6 & 41.2 & 137.4 & 5 \\
\hline PU5 & 27.1 & 5.8 & 255.8 & 193 & 3.2 & 3 & 50.1 & 3.5 & 9.7 & 34.4 & 2.1 & 87.1 & 2 \\
\hline PU6 & 26.8 & 5.7 & 481.9 & 192.8 & 7 & 4.3 & 39 & 2.5 & 45.8 & 27.3 & 1.6 & 65.3 & 3.7 \\
\hline PU7 & 28.5 & 6.1 & 115.2 & 96.5 & 3.3 & 0.2 & 24.2 & 2.2 & 6.1 & 19.1 & 0.3 & 40.9 & 1 \\
\hline PU8 & 29.5 & 5.4 & 72 & 42.7 & 1.8 & 1.1 & 11.4 & 0.5 & 6.3 & 17.4 & 0.5 & 3.6 & 1 \\
\hline PU9 & 28.4 & 6.3 & 30.2 & 74.3 & 0.8 & 3 & 14.7 & 1.1 & 48.6 & 4.2 & 0.5 & 1.4 & 1.2 \\
\hline J10 & 29.3 & 6.3 & 69.8 & 70.2 & 5. & 4 & & 1.8 & 46 & 2.3 & 0.8 & 3.7 & 3.2 \\
\hline J11 & 28.3 & 5 & 92.1 & 79.2 & 3.4 & 1.4 & 14.8 & 3.4 & 43.7 & 10.7 & 0.5 & 1.3 & 1.3 \\
\hline PU12 & 28.6 & 6 & 261.9 & 196 & 4.8 & 2 & 46.4 & 4.3 & 6.1 & 26.2 & 2.2 & 103.9 & 2 \\
\hline PU13 & 27.7 & 6.6 & 86.7 & 59 & 6.5 & 3.4 & 4.5 & 0.4 & 36.5 & 7.2 & 0.5 & 0.1 & 3 \\
\hline PU14 & 27.7 & 6.1 & 28.9 & 18.8 & 1.5 & 0.6 & 3.3 & 0.2 & 6.5 & 3.7 & 2.6 & 0.4 & 1 \\
\hline PU15 & 26.1 & 7.1 & 132.2 & 99.5 & 9.8 & 7.2 & 4.8 & 0.7 & 66.6 & 5.2 & 5.1 & 0.1 & 5 \\
\hline J16 & 26.5 & 5. & 335.7 & 246.5 & 12.1 & 0.1 & 60.2 & 2.7 & 6.1 & 44.8 & 8.4 & 112.1 & 3 \\
\hline & 28.5 & 6. & 435.6 & 330 & 21.1 & 3.1 & 67.3 & 4.5 & 24.4 & 35.5 & 38.6 & 135.8 & 6.5 \\
\hline PU18 & 29.1 & 5 & 20.5 & 17.7 & 1.2 & 0.4 & 3.2 & 0.3 & 6.8 & 3.3 & 1.8 & 0.5 & 0.5 \\
\hline Minimum & 26.1 & 4.9 & 20.5 & 17.7 & 0.8 & 0.1 & 3.2 & 0.2 & 6.1 & 2.3 & 0.3 & 0.1 & 0.5 \\
\hline Maximum & 29.5 & 7. & 936.4 & 697.2 & 28.4 & 7.6 & 161.5 & 14.3 & 66.6 & 90.2 & 80.4 & 302.4 & 10.3 \\
\hline Mean & 3.03 & 5.92 & 267.28 & 177.23 & 7.93 & 2.84 & 38.12 & 3.33 & 24.92 & 26.01 & 12.41 & 61.60 & 3.17 \\
\hline $\mathrm{Sd}$ & 0.94 & 0.55 & 248.26 & 169.28 & 7.54 & 2.16 & 41.20 & 3.55 & 19.77 & 25.56 & 22.09 & 78.91 & 2.46 \\
\hline $\begin{array}{l}\text { WHO } \\
\text { limits }\end{array}$ & 25 & $5-8.5$ & 300 & 500 & 75 & 30 & 200 & & 300 & 250 & 150 & 10 & 300 \\
\hline
\end{tabular}

Except $\mathrm{pH}, \mathrm{C.E}\left(\mu \mathrm{S} \mathrm{cm}{ }^{-1}\right), \mathrm{T}\left({ }^{\circ} \mathrm{C}\right)$ and $\mathrm{TH}\left(\mathrm{mgL}^{-1} \mathrm{CaCO}_{3}\right)$, all the other parameters are expressed in $\mathrm{mg} / \mathrm{L}$

The nitrate concentrations in analysed water vary from 0.10 to $302.4 \mathrm{mg} / \mathrm{L}$ in rainy season with an average of $61.60 \pm 79.37 \mathrm{mg} / \mathrm{L}$ and 0.10 to $302.21 \mathrm{mg} / \mathrm{L}$ in dry season with an average of $61.8 \mathrm{mg} / \mathrm{L}$.

The total hardness of the water attached mainly to the quantity of calcium varies from $0{ }^{\circ} \mathrm{F}$ with $10.3^{\circ} \mathrm{F}$ in rain season with an average of $3.17^{\circ} \mathrm{F}$ and $0^{\circ} \mathrm{F}$ with $10^{\circ} \mathrm{F}$ in dry season with an average of $3.44^{\circ} \mathrm{F}$.

We notice that within sight of the values of the concentrations of these two tables that there is no significant evolution of the parameters during the two seasons. Table 2 presents the average variation of these parameters in dry season.

Figures 3 to 6 present the distribution of some parameters during the two seasons. For nitrates on Figure 2, only wells PU1, PU16 and PU17 show a high rate of concentration. $55.56 \%$ of these wells have a concentration which exceeds standard WHO of $10 \mathrm{mg} / \mathrm{L}$. We also notice that there is no manifest seasonal evolution. 
Table 2. Physicochemical composition of the water samples of well in dry season

\begin{tabular}{|c|c|c|c|c|c|c|c|c|c|c|c|c|c|}
\hline Wells & $\mathrm{T}$ & $\mathrm{pH}$ & C.E & TDS & $\mathrm{Ca}^{2+}$ & $\mathrm{Mg}^{2+}$ & $\mathrm{Na}^{+}$ & $\mathrm{K}^{+}$ & $\mathrm{HCO}_{3}$ & $\mathrm{Cl}^{-}$ & $\mathrm{SO}_{4}{ }^{2-}$ & $\mathrm{NO}_{3}^{-}$ & $\mathrm{TH}$ \\
\hline PU1 & 28.31 & 6.60 & 936.75 & 697.00 & 28.28 & 7.03 & 161.57 & 7.78 & 18.34 & 90.47 & 80.93 & 302.21 & 110 \\
\hline PU2 & 28.60 & 5.63 & 415.16 & 108.00 & 4.20 & 2.80 & 21.2 & 2.10 & 39.5 & 13.0 & 0.50 & 24.42 & 6 \\
\hline PU3 & 26.57 & 5.06 & 554.10 & 289.00 & 14.85 & 4.75 & 54.65 & 13.58 & 14.40 & 48.28 & 39.30 & 98.63 & 6 \\
\hline PU4 & 27.05 & 6.53 & 542.08 & 406.0 & 17.33 & 2.91 & 100.44 & 7.35 & 19.08 & 78.6 & 41.30 & 139.03 & 6 \\
\hline PU5 & 28.20 & 6.65 & 258.40 & 213.00 & 3.60 & 3.38 & 53.30 & 3.53 & 22.75 & ). & 2.15 & 87.40 & 2 \\
\hline PU6 & 26.80 & 6.38 & 486.68 & 201.00 & 8.69 & 4.65 & 40.85 & 3.65 & 44.18 & 30.18 & 1.84 & 66.63 & 4 \\
\hline PU7 & 27.55 & 6.35 & 119.95 & 90.00 & 2.19 & 0.68 & 23.65 & 2.55 & 6.88 & 20.50 & 0.78 & 32.58 & 1 \\
\hline PU8 & 28.05 & 5.48 & 74.55 & 46.00 & 1.18 & 1.13 & 11.90 & 0.73 & 7.78 & 18.18 & 0.86 & 3.83 & 1 \\
\hline PU9 & 26.84 & 6.28 & 34.80 & 23.00 & 1.28 & 1.05 & 4.04 & 0.65 & 7.40 & 6.34 & 1.73 & 0.35 & 1 \\
\hline PU10 & 27.51 & 6.36 & 72.23 & 70.00 & 5.34 & 3.58 & 6.54 & 1.73 & 46.05 & 1.74 & 0.89 & 3.83 & 3 \\
\hline PU11 & 27.87 & 5.88 & 95.83 & 75.00 & 2.10 & 1.18 & 15.60 & 3.75 & 38.00 & 11.48 & 0.98 & 1.55 & 1 \\
\hline PU12 & 28.63 & 6.10 & 264.18 & 196.00 & 4.80 & 2.00 & 46.40 & 4.30 & 6.05 & 26.20 & 2.20 & 103.90 & 2 \\
\hline PU13 & 27.71 & 6.60 & 89.23 & 59.00 & 6.50 & 3.40 & 4.50 & 0.40 & 36.30 & 7.20 & 0.50 & 0.10 & 3 \\
\hline PU14 & 27.70 & 6.20 & 30.00 & 20.00 & 1.60 & 0.60 & 3.75 & 0.20 & 6.33 & 4.25 & 2.50 & 0.90 & 1 \\
\hline PU15 & 26.12 & 7.00 & 135.23 & 99.00 & 9.80 & 7.20 & 4.80 & 0.70 & 65.60 & 5.20 & 5.10 & 0.10 & 5 \\
\hline PU16 & 26.52 & 5.90 & 338.25 & 247.00 & 12.14 & 0.10 & 60.21 & 2.70 & 6.06 & 44.80 & 8.40 & 112.11 & 3 \\
\hline PU17 & 28.53 & 6.10 & 438.78 & 329.00 & 21.10 & 3.10 & 67.30 & 4.50 & 23.20 & 35.50 & 38.60 & 135.80 & 7 \\
\hline PU18 & 27.66 & 5.31 & 19.73 & 17.00 & 0.99 & 0.34 & 3.56 & 0.12 & 6.25 & 3.33 & 2.19 & 0.13 & 0 \\
\hline Minimum & 26.12 & 5.06 & 19.73 & 17.00 & 0.99 & 0.10 & 3.56 & 0.12 & 6.05 & 1.74 & 0.50 & 0.10 & 0 \\
\hline Maximum & 28.63 & 7.00 & 936.75 & 697.00 & 28.28 & 7.20 & 161.57 & 13.58 & 65.60 & 90.47 & 80.93 & 302.21 & 10 \\
\hline Mean & 27.57 & 6.13 & 272.55 & 176.94 & 8.11 & 2.77 & 38.02 & 3.35 & 23.01 & 26.78 & 12.82 & 61.86 & 3.44 \\
\hline $\mathrm{Sd}$ & 0.77 & 0.51 & 249.36 & 173.36 & 7.83 & 2.14 & 41.66 & 3.42 & 17.90 & 25.68 & 22.31 & 79.37 & 2.71 \\
\hline $\begin{array}{l}\text { WHO } \\
\text { limits }\end{array}$ & 25 & $0.5-8.5$ & 300 & 500 & 75 & 30 & 200 & & 300 & 250 & 150 & 10 & 300 \\
\hline
\end{tabular}

Except $\mathrm{pH}$, C.E $\left(\mu \mathrm{Scm}^{-1}\right), \mathrm{T}\left({ }^{\circ} \mathrm{C}\right)$ and $\mathrm{TH}\left(\mathrm{mgL}^{-1} \mathrm{CaCO}_{3}\right)$, all the other parameters are expressed in $\mathrm{mg} / \mathrm{L}$

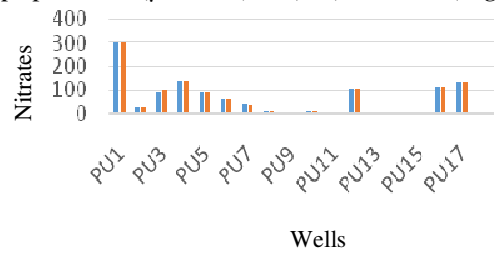

-NO3_rainseason NO3_dry season

Figure 3. Distribution of the concentration of the ions nitrates

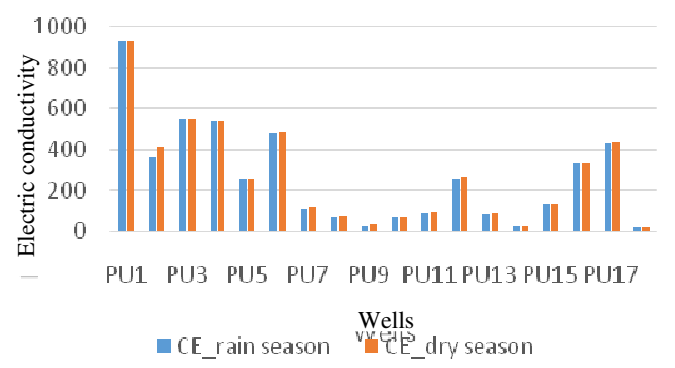

Figure 5. Distribution of electric conductivity

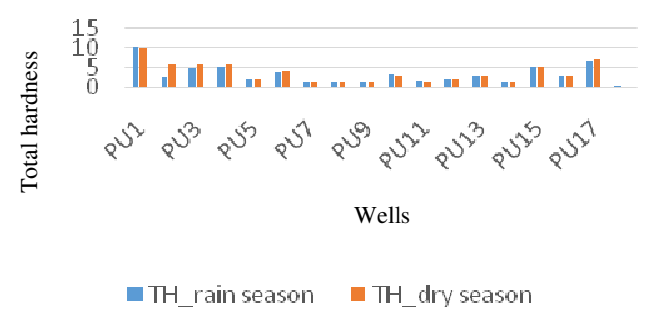

Figure 4. Distribution of total hardness

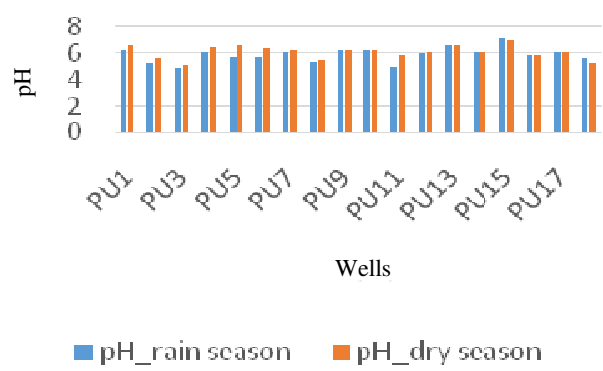

Figure 6. Distribution of the $\mathrm{pH}$ 
Table 3. presents the monthly median values (January in December 2014)

\begin{tabular}{cccccccccccccc}
\hline Wells & $\mathrm{T}$ & $\mathrm{pH}$ & $\mathrm{C} . \mathrm{E}$ & $\mathrm{TDS}$ & $\mathrm{Ca}^{2+}$ & $\mathrm{Mg}^{2+}$ & $\mathrm{Na}^{+}$ & $\mathrm{K}^{+}$ & $\mathrm{HCO}_{3}$ & $\mathrm{Cl}^{-}$ & $\mathrm{SO}_{4}^{2-}$ & $\mathrm{NO}_{3}{ }^{-}$ & $\mathrm{TH}$ \\
\hline PU1 & 28.2 & 6.4 & 936.5 & 697 & 28.4 & 7.4 & 161.5 & 7.8 & 18.4 & 90.3 & 80.5 & 302.4 & 11 \\
PU2 & 28.6 & 5.4 & 388.8 & 109 & 4.5 & 2.8 & 20.8 & 2.2 & 41.7 & 12.7 & 0.4 & 24.1 & 2 \\
PU3 & 27.3 & 5 & 551.9 & 276 & 12.4 & 4.5 & 54.6 & 14.1 & 14.6 & 47.2 & 37.1 & 91.5 & 5 \\
PU4 & 27.7 & 6.3 & 542 & 400 & 16.9 & 2.6 & 100 & 7.5 & 16.3 & 78 & 41.3 & 137.9 & 5 \\
PU5 & 27.6 & 6.1 & 256.5 & 201 & 3.4 & 3.1 & 51.2 & 3.5 & 15.5 & 35.1 & 2.1 & 87.1 & 2 \\
PU6 & 26.9 & 5.9 & 483.5 & 195 & 7.8 & 4.4 & 39.6 & 2.9 & 44.2 & 28.3 & 1.7 & 65.8 & 4 \\
PU7 & 28.2 & 6.2 & 116.9 & 96 & 3.2 & 0.4 & 24.2 & 2.3 & 6.3 & 19.7 & 0.4 & 39.2 & 1 \\
PU8 & 29 & 5.5 & 72.9 & 44 & 1.6 & 1.1 & 11.6 & 0.6 & 7.2 & 17.7 & 0.6 & 3.7 & 1 \\
PU9 & 27.9 & 6.4 & 31.8 & 53 & 1 & 2.2 & 10.2 & 1 & 32 & 4.9 & 1 & 1 & 1 \\
PU10 & 28.7 & 6.3 & 70.5 & 70 & 5.5 & 3.7 & 6.1 & 1.8 & 46.2 & 2 & 0.8 & 3.8 & 3 \\
PU11 & 28.1 & 5.3 & 93.6 & 78 & 3 & 1.3 & 15.1 & 3.5 & 41.7 & 11 & 0.6 & 1.4 & 1 \\
PU12 & 28.6 & 6 & 262.7 & 196 & 4.8 & 2 & 46.4 & 4.3 & 5.9 & 26.2 & 2.2 & 103.9 & 2 \\
PU13 & 27.7 & 6.6 & 87.6 & 59 & 6.5 & 3.4 & 4.5 & 0.4 & 36.4 & 7.2 & 0.5 & 0.1 & 3 \\
PU14 & 27.7 & 6.1 & 29.2 & 19 & 1.5 & 0.6 & 3.4 & 0.2 & 6.5 & 3.7 & 2.5 & 0.6 & 1 \\
PU15 & 26.1 & 7 & 133.3 & 99 & 9.8 & 7.2 & 4.8 & 0.7 & 66.1 & 5.2 & 5.1 & 0.1 & 5 \\
PU16 & 26.5 & 5.9 & 336.6 & 246 & 12.1 & 0.1 & 60.2 & 2.7 & 5.8 & 44.8 & 8.4 & 112.1 & 3 \\
PU17 & 28.5 & 6.1 & 436.7 & 330 & 21.1 & 3.1 & 67.3 & 4.5 & 23.7 & 35.5 & 38.6 & 135.8 & 7 \\
PU18 & 28.6 & 5.5 & 20.3 & 17 & 1.1 & 0.4 & 3.3 & 0.2 & 6.6 & 3.2 & 2 & 0.3 & 0 \\
Minimum & 26.1 & 5 & 20.3 & 17 & 1 & 0.1 & 3.3 & 0.2 & 5.8 & 2 & 0.4 & 0.1 & 0 \\
Maximum & 28.6 & 6.4 & 936.5 & 697 & 28.4 & 7.4 & 161.5 & 7.8 & 18.4 & 90.3 & 80.5 & 302.4 & 11 \\
Mean & 27.88 & 6.00 & 269.52 & 176.94 & 8.03 & 2.79 & 38.04 & 3.34 & 24.17 & 26.26 & 12.5461 .71 & 3.17 \\
Sd & 0.79 & 0.50 & 248.77 & 170.71 & 7.62 & 2.13 & 41.37 & 3.51 & 18.20 & 25.61 & 22.1579 .02 & 2.71 \\
WHO limits & 25 & $6.5-8.5$ & 300 & 500 & 75 & 30 & 200 & & 300 & 250 & 150 & 10 & 300 \\
\hline
\end{tabular}

Except $\mathrm{pH}, \mathrm{C.E}\left(\mu \mathrm{S \textrm {cm } ^ { - 1 }}\right), \mathrm{T}\left({ }^{\circ} \mathrm{C}\right)$ and $\mathrm{TH}\left(\mathrm{mgL}^{-1} \mathrm{CaCO}_{3}\right)$, all the other parameters are expressed in $\mathrm{mg} / \mathrm{L}$

Associations between the monthly median values of the parameters were given starting from a matrix of correlation (Table 4).

Table 4. Correlation matrix of the monthly median values

\begin{tabular}{cccccccccccccc}
\hline Parameter & $\mathrm{T}$ & $\mathrm{pH}$ & $\mathrm{C} . \mathrm{E}$ & $\mathrm{TDS}$ & $\mathrm{Ca}^{2+}$ & $\mathrm{Mg}^{2+}$ & $\mathrm{Na}^{+}$ & $\mathrm{K}^{+}$ & $\mathrm{HCO}_{3}^{-}$ & $\mathrm{Cl}^{-}$ & $\mathrm{SO}_{4}^{2-}$ & $\mathrm{NO}_{3}^{-}$ & $\mathrm{TH}$ \\
\hline $\mathrm{T}$ & 1.00 & & & & & & & & & & & & \\
$\mathrm{pH}$ & -0.32 & 1.00 & & & & & & & & & & & \\
$\mathrm{C} . \mathrm{E}$ & -0.15 & -0.06 & 1.00 & & & & & & & & & & \\
$\mathrm{TDS}$ & -0.10 & 0.12 & $\mathbf{0 . 9 4}$ & 1.00 & & & & & & & & & \\
$\mathrm{Ca}^{2+}$ & -0.17 & 0.23 & $\mathbf{0 . 8 6}$ & $\mathbf{0 . 9 2}$ & 1.00 & & & & & & & & \\
$\mathrm{Mg}^{2+}$ & -0.33 & 0.42 & $\mathbf{0 . 5 6}$ & $\mathbf{0 . 5 3}$ & $\mathbf{0 . 5 9}$ & 1.00 & & & & & & & \\
$\mathrm{Na}^{+}$ & -0.06 & 0.08 & $\mathbf{0 . 9 2}$ & $\mathbf{0 . 9 9}$ & $\mathbf{0 . 8 7}$ & 0.42 & 1.00 & & & & & & \\
$\mathrm{~K}^{+}$ & -0.11 & -0.33 & $\mathbf{0 . 7 4}$ & $\mathbf{0 . 6 8}$ & $\mathbf{0 . 6 0}$ & 0.36 & $\mathbf{0 . 6 6}$ & 1.00 & & & & & \\
$\mathrm{HCO}_{3}^{-}$ & -0.31 & 0.35 & -0.08 & -0.17 & 0.00 & $\mathbf{0 . 5 9}$ & -0.28 & -0.20 & 1.00 & & & & \\
$\mathrm{Cl}^{-}$ & -0.13 & 0.01 & $\mathbf{0 . 9 0}$ & $\mathbf{0 . 9 5}$ & $\mathbf{0 . 8 2}$ & 0.35 & $\mathbf{0 . 9 7}$ & $\mathbf{0 . 7 3}$ & -0.33 & 1.00 & & & \\
$\mathrm{SO}_{4}{ }^{2-}$ & -0.01 & 0.08 & $\mathbf{0 . 8 6}$ & $\mathbf{0 . 9 3}$ & $\mathbf{0 . 9 2}$ & $\mathbf{0 . 5 3}$ & $\mathbf{0 . 9 0}$ & $\mathbf{0 . 7 1}$ & -0.17 & $\mathbf{0 . 8 6}$ & 1.00 & & \\
$\mathrm{NO}_{3}{ }^{-}$ & -0.04 & 0.10 & $\mathbf{0 . 9 0}$ & $\mathbf{0 . 9 8}$ & $\mathbf{0 . 8 7}$ & 0.42 & $\mathbf{0 . 9 8}$ & $\mathbf{0 . 6 3}$ & -0.30 & $\mathbf{0 . 9 3}$ & $\mathbf{0 . 8 8}$ & 1.00 & \\
$\mathrm{TH}^{-}$ & -0.21 & 0.31 & $\mathbf{0 . 8 5}$ & $\mathbf{0 . 8 9}$ & $\mathbf{0 . 9 6}$ & $\mathbf{0 . 7 7}$ & $\mathbf{0 . 8 1}$ & $\mathbf{0 . 5 7}$ & 0.16 & $\mathbf{0 . 7 4}$ & $\mathbf{0 . 8 9}$ & $\mathbf{0 . 8 2}$ & 1.00 \\
\hline
\end{tabular}

Significant correlations marked to $p<0.05(N=18$ observations $)$ 


\section{Correlation matrix}

In this hydrochemical study, the relation between the variables or descriptors chemical has been established by calculating the matrix of correlation in order to include/understand association between these variables. As it's shown on Table 4, the variables $\mathrm{Ca}^{2+}, \mathrm{Na}^{+}, \mathrm{Cl}^{-}$ and $\mathrm{SO}_{4}{ }^{2-}$ are very strongly correlated with the TDS $(\mathrm{R}>0.9) . \mathrm{K}^{+}$and $\mathrm{Mg}^{2+}$ are fairly correlated with the TDS ( $\mathrm{r}=0.68$ and 0.53 ). C.E and TDS are strongly correlated positively, which shows that the dissolved total solids translate electric conductivity correctly. In addition, the chemical variables $\mathrm{Na}^{+}$and $\mathrm{K}^{+}$present a good correlation with $\mathrm{Cl}^{-}$and $\mathrm{SO}_{4}{ }^{2-}$, which supposes the presence of chlorides and sulphates of these two major cations in the aquifer. The positive correlation between $\mathrm{NO}_{3}{ }^{-}$and the captions $\mathrm{Ca}^{2+}(\mathrm{r}=0.87), \mathrm{Na}^{+}(\mathrm{r}=0.98)$, $\mathrm{K}^{+}(\mathrm{r}=0.63)$ supposes a contamination of water by organic matter ${ }^{8}$. The null correlation between $\mathrm{Ca}^{2+}$ and $\mathrm{HCO}_{3}{ }^{-}$shows the absence of carbonates in the aquifer.

\section{Multivariate statistical analysis}

The multivariate statistical analysis of the data describes the whole of the variables taken overall and to extract the essence of information from it. These statistical analyses are the best and are often the only effective solution to analyse a great mass of information generated starting from the hydrochemical data of the groundwater ${ }^{9-11}$. In order to better interpret the hydrochemical variables of unconfined water AQ1, ascending hierarchical classification (HCA) and the analysis in principal components (ACP) were carried out by using the software of statistical analysis STATISCA 7.1 ${ }^{12}$.

\section{Ascending hierarchical classification (HCA)}

According to Davis ${ }^{13}$, ascending hierarchical classification (HCA) is a hierarchical technique of classification of the data which is largely applied in sciences of the Earth and which is often used in the classification of the hydrogeochemical data 9

The main result of the HCA carried out on the 18 subterranean water samples is the dendrogram (Figure 7). For this study, the Euclidean distance was selected as the measurement of distance, or measures similarity between the sites of sampling. The sites of taking away with the greatest similarity are initially gathered. Then, of the groups of samples are joined with a mechanism of coupling and the stages are repeated until all the observations were classified.

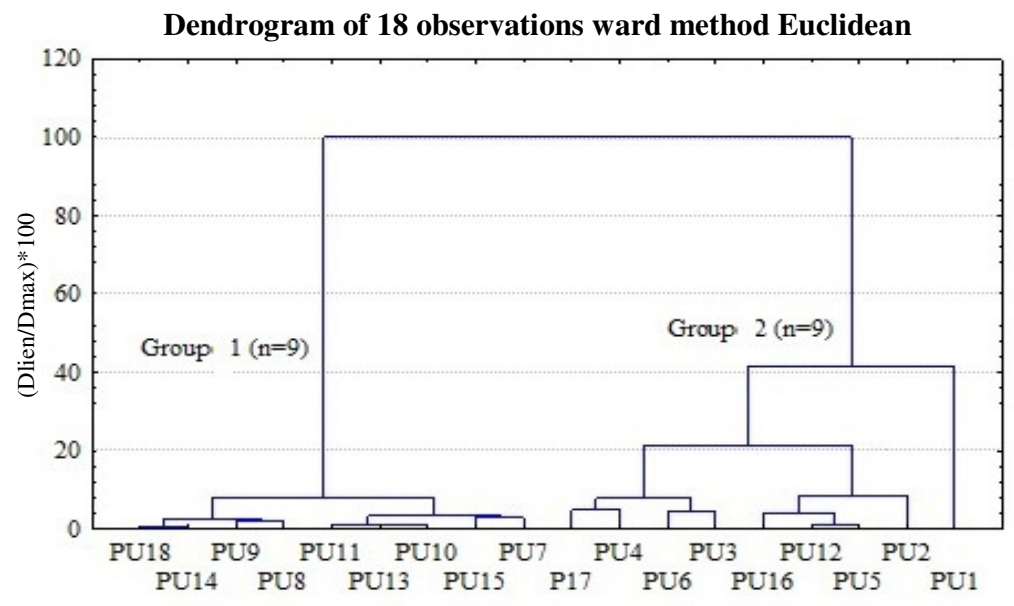

Figure 7. Dendrogram of 18 water wells 
The regrouping in two groups or families of water gave the most satisfactory results (thus answering the objectives of the method of classification). The observation of the dendrogram applied to the 18 samples of the zone of study reveals some indications on the level of similarity between the samples (Figure 8). The samples coming from group 1, PU10 and PU11, PU8 and PU9, PU7 and PU15, PU14 and PU18 present a great similarity. In group 2, the water samples PU5 and PU12, PU3 and PU6, PU4 and PU17 present also a great similarity. Water of group 1 has the shortest distance from connection between them and thus, has the greatest resemblance compared to group 2. To describe the characteristics of each group of samples, the median values of the parameters used in this classification shown in the Figures 8a, b and c. All the parameters discriminate the two groups except for the temperature and of the $\mathrm{pH}$.

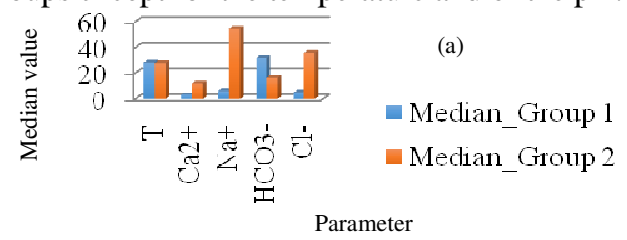
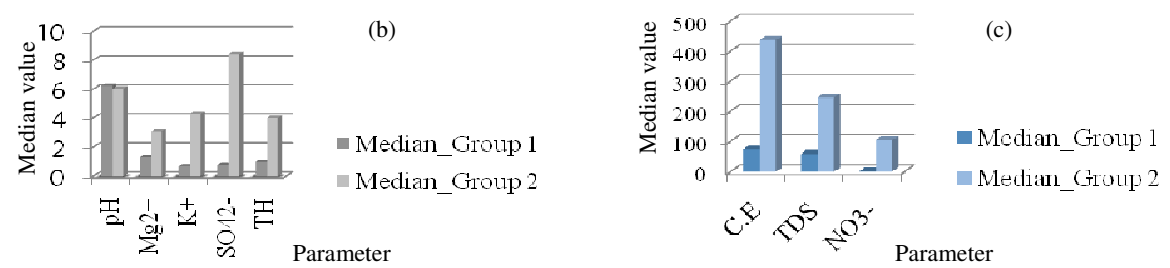

Figure 8. Comparison of the median values of the parameters between the two groups

\section{Factorial analysis}

The factorial analysis (AF) is one of the methods of analysis of the most used multidimensional data $^{13}$. This multidimensional analysis of the data is a factorial and linear method which treats numerical characters (variable). It makes it possible to reduce the parameters while emphasizing those which are most determining. The component count to be kept is founded on the criterion of Kaiser $^{14}$, according to which the eigenvalues higher or equal to 1 are taken into account. The first $\mathrm{F} 1$ factor is that which expresses the strongest percentage of the original variance. The second F2 factor, independent of the first, which is that, expresses most of the residual variance and so on. The layout of the factorial weights is presented on Figure 9.

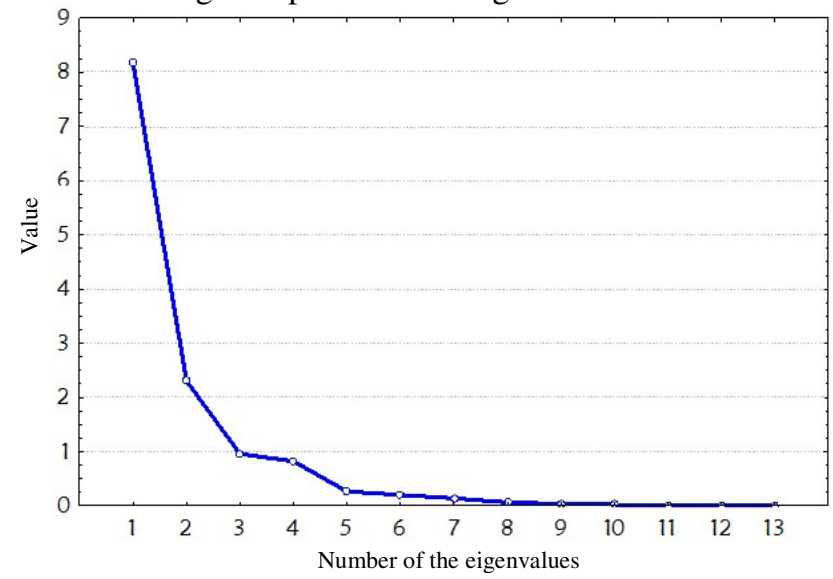

Figure 9. Layout of the eigenvalues 
Two factors were extracted and count for $80.61 \%$ of the original variance. The F1 factor accounts for $62.87 \%$ of the total variance. It is strongly and positively correlated with variables C.E, TDS, $\mathrm{Ca}^{2+}, \mathrm{Na}^{+}, \mathrm{Cl}^{-}, \mathrm{SO}_{4}{ }^{2-}$ and $\mathrm{NO}_{3}^{-}$(weight factorial $>0,9$ ) and also correlated with $\mathrm{TH}$ (factorial weight 0.87 ) and $\mathrm{K}^{+}$(factorial weight 0.77 ). The first factor represents mainly the mineralization of water and hardness (Table 5). The presence of nitrates in the F1 factor could translate a contamination of water by the organic matter coming from waste water ${ }^{15}$. The second $\mathrm{F} 2$ factor accounts for $17.74 \%$ of the original variance. It is correlated with variables $\mathrm{HCO}_{3}{ }^{-}, \mathrm{Mg}^{2+}$ and $\mathrm{pH}$. It represents the dissolution of carbonated minerals of the magnesium whose $\mathrm{pH}$ of water controls dissolution ${ }^{8}$. The significant factorial weights are presented in fat in Table 5.

Table 5. Factorial weights of the variables

\begin{tabular}{ccc}
\hline Code & Factor 1 & Factor 2 \\
\hline $\mathrm{T}$ & -0.07 & -0.57 \\
$\mathrm{pH}$ & 0.01 & $\mathbf{0 . 7 3}$ \\
$\mathrm{C} . \mathrm{E}$ & $\mathbf{0 . 9 5}$ & 0.09 \\
$\mathrm{TDS}_{\mathrm{Ca}^{2+}}$ & $\mathbf{0 . 9 9}$ & 0.10 \\
$\mathrm{Mg}^{2+}$ & $\mathbf{0 . 9 1}$ & 0.28 \\
$\mathrm{Na}^{+}$ & $\mathbf{0 . 9 8}$ & $\mathbf{0 . 7 7}$ \\
$\mathrm{K}^{+}$ & $\mathbf{0 . 7 7}$ & -0.01 \\
$\mathrm{HCO}_{3}{ }^{-}$ & -0.25 & -0.15 \\
$\mathrm{Cl}^{-}$ & $\mathbf{0 . 9 5}$ & $\mathbf{0 . 8 3}$ \\
$\mathrm{SO}_{4}{ }^{2-}$ & $\mathbf{0 . 9 5}$ & -0.07 \\
$\mathrm{NO}_{3}{ }^{-}$ & $\mathbf{0 . 9 7}$ & -0.08 \\
$\mathrm{TH}^{-}$ & $\mathbf{0 . 8 7}$ & 0.44 \\
\hline Eigenvalue & 8.17 & 2.31 \\
Total \% & 62.87 & 17.74 \\
variance & & \\
Cumulated & 62.87 & 80.61 \\
\%variance & & \\
\hline Significant factorial weights in fat & $>0.7)$
\end{tabular}

Table 6 presents the factorial scores of the water samples on the factors F1 and F2. More important is the value of the factorial score, more important is the process described by the factor corresponding to the level of the water points. Taking into consideration this table, well PU1 is atypical because it has a factorial score of 2.88 on F1. In addition, well PU15 has the highest factorial score (2.98) on F2.

Table 6. Factorial scores of the water samples

\begin{tabular}{ccc}
\hline Code & Factor 1 & Factor 2 \\
\hline PU1 & 2.88 & 0.64 \\
PU2 & -0.37 & -0.19 \\
PU3 & 1.10 & -0.67 \\
PU4 & 1.33 & -0.19 \\
PU5 & 0.01 & -0.17 \\
PU6 & 0.02 & 0.91 \\
PU7 & -0.45 & -0.74 \\
\hline
\end{tabular}




\begin{tabular}{ccc}
\hline PU8 & -0.61 & -1.24 \\
PU9 & -0.86 & 0.32 \\
PU10 & -0.71 & 0.70 \\
PU11 & -0.64 & -0.38 \\
PU12 & 0.07 & -0.84 \\
PU13 & -0.73 & 0.94 \\
PU14 & -0.83 & -0.46 \\
PU15 & -0.68 & 2.98 \\
PU16 & 0.35 & -0.48 \\
PU17 & 0.94 & 0.07 \\
PU18 & -0.82 & -1.22 \\
\hline
\end{tabular}

Figures 10 and 11 represent distribution of the factorial scores on the whole of the sampled water wells.

The process of mineralization of water and total hardness represented by the F1 factor is more important in wells PU1, PU3, PU4 and PU7. In the same way, the process concerned by the factor F2 (dissolution of carbonated minerals) is done more in a way accentuated in wells PU6, PU13 and PU15.

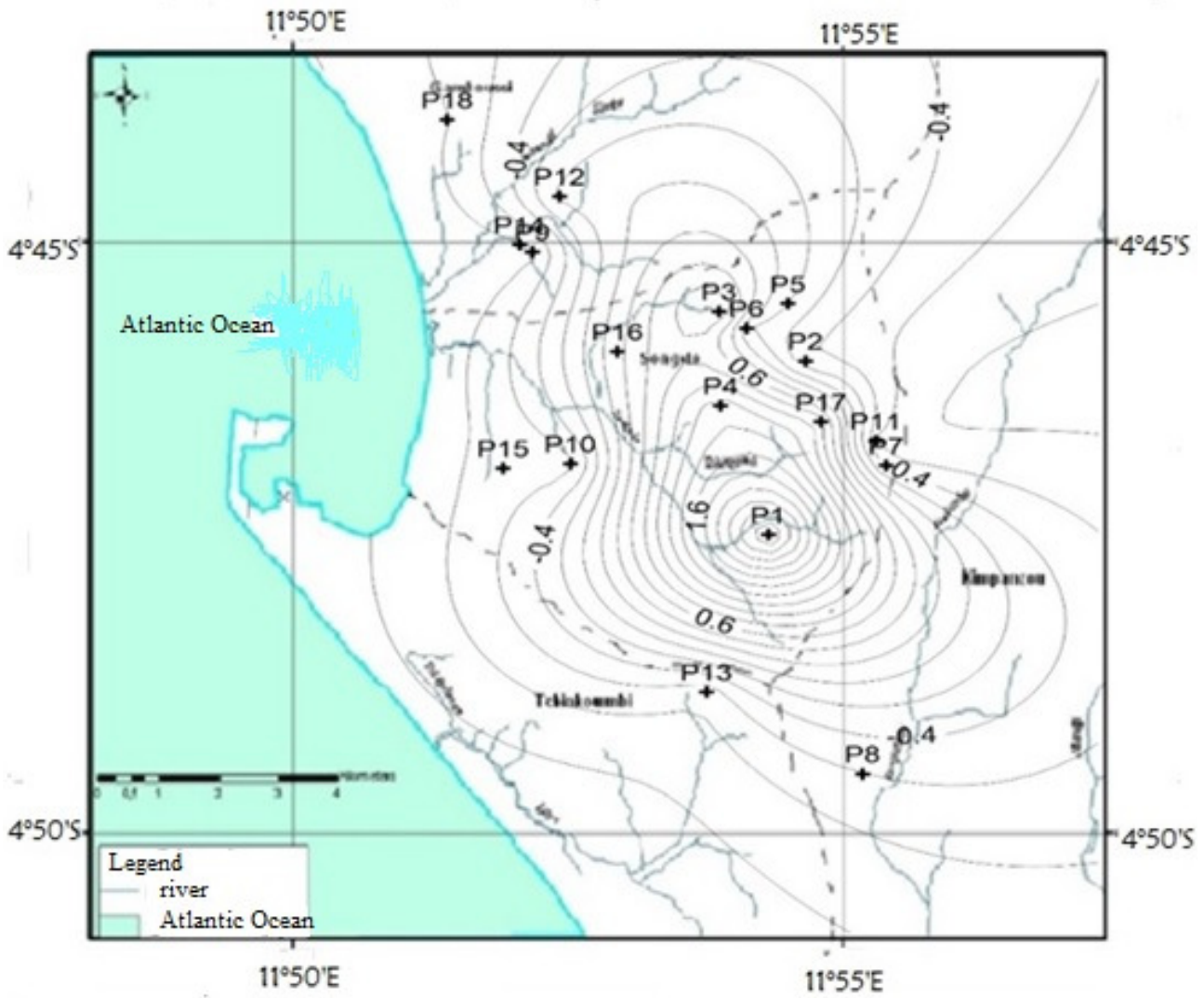

Figure 10. Distribution of the factorial scores on F1 


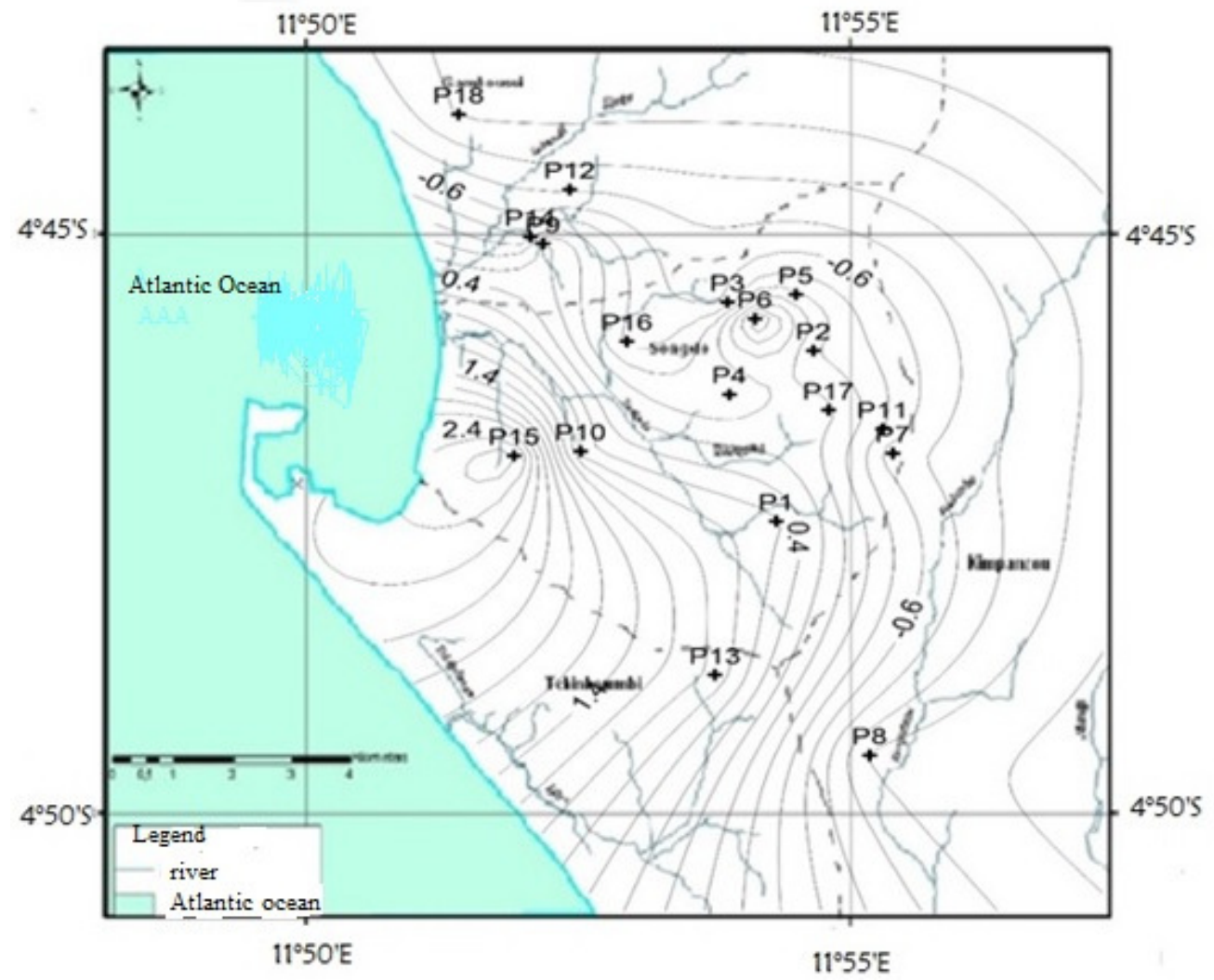

Figure 11. Distribution of the factorial scores on F2

\section{Conclusion}

The hydrochemical study of water of aquifer AQ1 of the zone of study showed the concentrations in major ions are within the limits for the drink water except for the nitrates whose concentrations exceed the limiting value of $10 \mathrm{mg} / \mathrm{L}$ for the drinking water including $55.56 \%$ of the water wells. This water is soft and is slightly acid. As a whole mineralization is weak except the well PU1 which is presented in the form of atypical.

Ascending hierarchical classification made it possible to gather the water wells in two groups which are discriminated by mineralization, total hardness, the contamination in ions nitrates. These discriminating parameters of two groups were highlighted by the factorial analysis.

The application of the multivariate statistical methods in this study showed their need on the description of the processes which control the chemical composition of studied water.

\section{References}

1. Ledoux E, J Geophysical Res., 2004, 109, D14105, DOI:10.1029/2003JD004403

2. Mor S S, Ravindra K, Dahiya R P and Chandra A, Environ Monit Assess., 2006, 118, 435-456; DOI:10.1007/s10661-006-1505-7

3. Jain P, Sharma J D, Sohu D and Sharma P, Int J Environ Sci Tech., 2005, 2(4) 373-379. 
4. Tathy C, Matini L, Mabiala B, Antoine F and Moukandi N' Kaya G D, Res J Appl Sci., 2010, 5(5), 361-369.

5. Moukolo N, Hydrogéologie, 1992, 1-2, 47-58.

6. Moukandi N'Kaya, Thèse de doctorat unique, Université Marien Ngouabi Congo, 2012, 127.

7. Nkounkou Tomodiatounga D, Mabiala B and Moukandi Nkaya G, 2016, 4(9), 95109; DOI:10.4236/gep.2016.49008

8. Yohana Mtoni, Ibrahimu Chikira Mjemah, Charles Bakundukize, Marc Van Camp, Kristine Martens and Kristine Walraevens, Environ Earth Sci., 2013, 70(3), 10911111; DOI:10.1007/s12665-012-2197-7

9. Matini L, Moutou et J M and Kongo Mantono M S, Congo, Afrique Science, 2009, 5(1), 82-98.

10. Jayakumar R, Dhanakumar S, Kalaiselvi K and Palanivel M, 2015, 4(3), 728-735; DOI: $10.7598 /$ cst2015.1066

11. Shreya Das and Nag S K, 2015, 7(2), 873-888; DOI:10.1007/s13201-015-0299-6

12. StatSoft Inc. (2008) Statistica (Data Analysis Software System), version 7. 2300 East, $14^{\text {th }}$ St, Tulsa, OK 74104 Steinhorst R K and Williams R E, 1985, Discrimination of groundwater

13. Davis S N, Whittemore D O and Fabryka-Martin J, Groundwater, 1998, 36(2), 338350; DOI:10.1111/j.1745-6584.1998.tb01099.x

14. Kaiser H F, The Varimax Criterion for Analytical Rotation in Factor Analysis. Psychometrika, 1958, 23b, 187-200.

15. Pathmakumara Jayasingha, Pitawala A and Dharmagunawardhane H A, Environ Earth Sci., 2014, 71(11), 4925-4937; DOI:10.1007/s12665-013-2885-y 